\title{
Notes
}

\section{Phenylethanoid Glycosides from Digitalis purpurea $\mathbf{L}$.}

\author{
Qinglong Jin, Hong-Guang Jin, Ji Eun Shin, Jongki Hong, ${ }^{\dagger}$ and Eun-Rhan Woo* \\ College of Pharmacy, Chosun University, Gwangju 501-759, Korea. E-mail: wooer@chosun.ac.kr \\ College of Pharmacy, Kyung Hee University, Seoul 130-701, Korea \\ Received July 28, 2010, Accepted November 1, 2010
}

Key Words: Digitalis purpurea, Scrophulariaceae, 2-(3,4-Dihydroxyphenyl)ethyl- $O$ - $\alpha$-L-rhamnopyranosyl(1-6)-4-O-[(E)-feruloyl]- $\beta$-D-glucopyranoside, Purpureaside D (1), 2-(3,4-Dihydroxyphenyl)ethyl- $O$ - $\alpha$-Lrhamnopyranosyl-(1-6)-O- $\beta$-D-glucopyranosyl-(1-3)-4- $O-[(E)$-feruloyl]- $\beta$-D-glucopyranoside, Purpureaside E (3), Phenylethanoid glycoside

Digitalis purpurea is a biennial herb of the Scrophulariaceae family, and is commonly used to treat congestive heart failure. ${ }^{1-2}$ Moreover, it was also reported that Digitalis glycosides have potent anticancer effects. ${ }^{3}$ Recently, we isolated five phenylethanoid glycosides from this plant and studied for their effects on the expression of inducible nitric oxide synthase and their ability to induce GST and their protective efficacies against aflatoxin B1 (AFB1)-induced cytotoxicity. ${ }^{4-6}$ In a continuation of the phytochemical study on D. purpurea, we now report the isolation and structural elucidation of two new phenylethanoid glycosides, purpureaside D (1) and purpureaside E (3), together with two known phenylethanoid glycosides, scroside D (2), and forsythiaside (4) as well as their antioxidative activity on the NBT superoxide scavenging assay.

The leaves of $D$. purpurea were extracted with $\mathrm{MeOH}$ at room temperature for three times. The $\mathrm{MeOH}$ extract was suspended in water and then partitioned sequentially with equal volumes of dichloromethane, ethyl acetate, and $n$-butanol. An ethylacetate soluble fraction of the $\mathrm{MeOH}$ extract was purified by silica gel, Sephadex LH 20, and LiChroprep RP-18 column

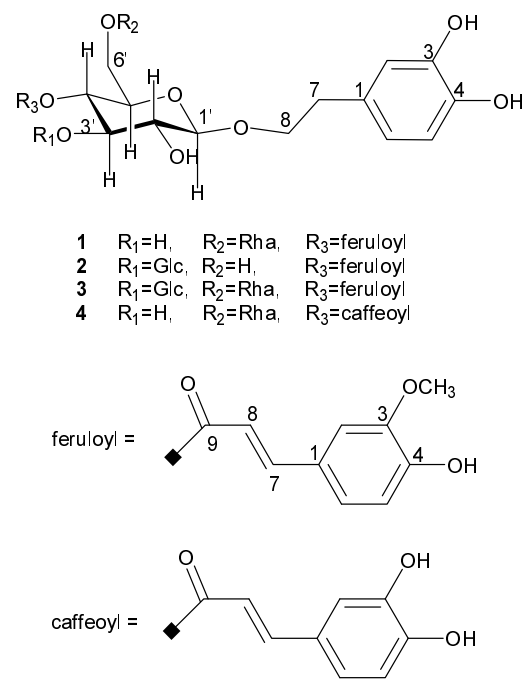

Chart 1. Structures of Compounds 1-4 from Digitalis purpurea L. chromatography yielded two new phenylethanoid glycosides, named purpureaside D (1), and purpureaside E (3) together with two known phenylethanoid glycosides, scroside D (2), and forsythiaside (4) (Chart 1). The structure of new compounds were determined to be 2-(3,4-dihydroxyphenyl)ethyl- $O-\alpha-\mathrm{L}-$ rhamnopyranosyl-(1-6)-4- $O$-[(E)-feruloyl]- $\beta$-D-glucopyranoside (1), 2-(3,4-dihydroxyphenyl)ethyl- $O$ - $\alpha$-L-rhamnopyranosyl-(1-6)- $O-\beta$-D-glucopyranosyl-(1-3)-4- $O-[(E)$-feruloyl $]-\beta-$ D-glucopyranoside (3), respectively, on the basis of spectral analysis.

Compound $\mathbf{1}$ was obtained as an yellow amorphous powder, with $[\alpha]_{\mathrm{D}}^{25}-191.3^{\circ}$. Its molecular formula was determined to be $\mathrm{C}_{30} \mathrm{H}_{38} \mathrm{O}_{15}$ by HR-FAB-MS ([M+Na $]^{+}$at $m / z$ 661.2106, calc.
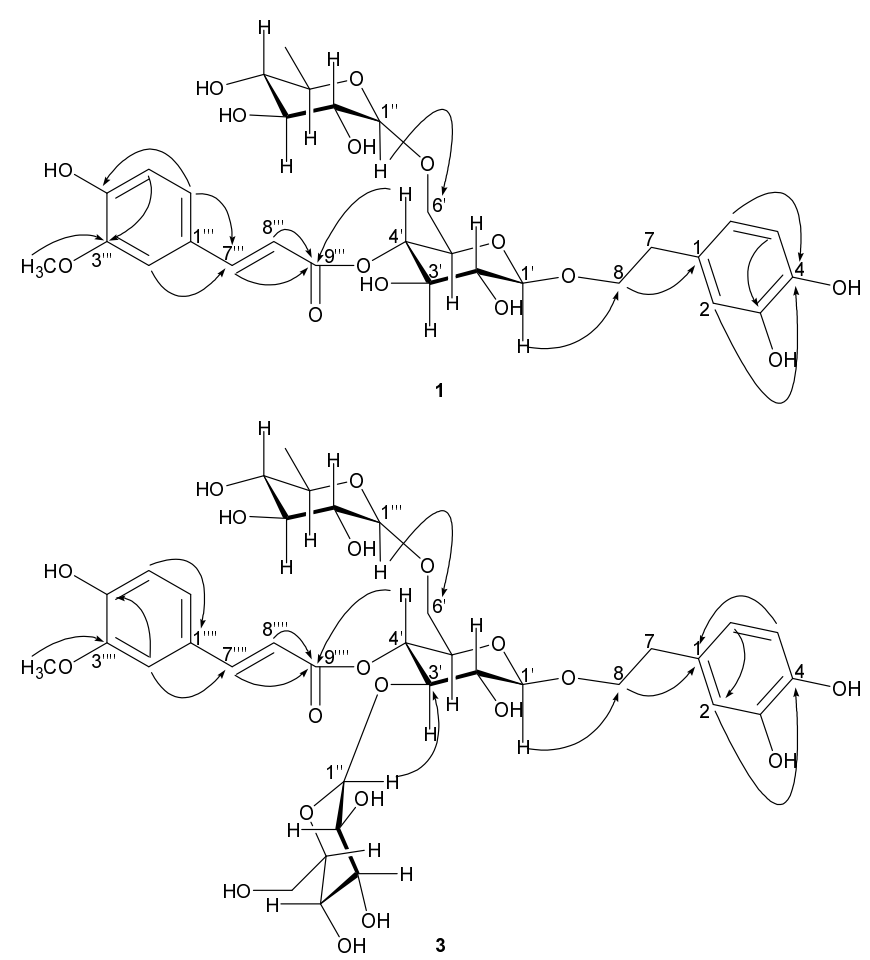

Figure 1. Key HMBC Correlations for Compounds $\mathbf{1}$ and $\mathbf{3}$. 
Table 1. ${ }^{1} \mathrm{H}-\mathrm{NMR}(500 \mathrm{MHZ})$ and ${ }^{13} \mathrm{C}-\mathrm{NMR}$ (125 MHz) Spectral Data of Compounds $\mathbf{1}$ and $\mathbf{3}$

\begin{tabular}{|c|c|c|c|c|}
\hline \multirow{2}{*}{$\mathbf{C}$} & \multicolumn{2}{|l|}{$\mathbf{1}^{a}$} & \multicolumn{2}{|c|}{$3^{b}$} \\
\hline & $\delta_{\mathrm{H}}$ & $\delta_{\mathrm{C}}$ & $\delta_{\mathrm{H}}$ & $\delta_{\mathrm{C}}$ \\
\hline \multicolumn{5}{|l|}{ Aglycone } \\
\hline 1 & & 131.55 & & 129.20 \\
\hline 2 & $6.70(\mathrm{~d}, 2.0)$ & 117.26 & $6.62(\mathrm{~d}, 2.0)$ & 116.33 \\
\hline 3 & & 146.26 & & 146.86 \\
\hline 4 & & 144.83 & & 143.53 \\
\hline 5 & $6.69(\mathrm{~d}, 8.0)$ & 116.51 & $6.63(\mathrm{~d}, 8.0)$ & 115.50 \\
\hline 6 & $6.57(\mathrm{dd}, 8.0,2.0)$ & 121.43 & $6.50(\mathrm{dd}, 8.0,2.0)$ & 119.53 \\
\hline 7 & $2.81(\mathrm{~m})$ & 36.80 & $2.69(\mathrm{~m})$ & 35.07 \\
\hline 8 & $3.73,3.99$ (each, dd, 16.0, 8.0) & 72.51 & $3.65,3.84$ (each, m) & 70.28 \\
\hline \multicolumn{5}{|c|}{ Inner glucose } \\
\hline $1^{\prime}$ & $4.37(\mathrm{~d}, 8.0)$ & 104.65 & $4.42(\mathrm{~d}, 8.0)$ & 102.23 \\
\hline $2^{\prime}$ & $3.31(\mathrm{~m})$ & 75.32 & $3.56(\mathrm{~m})$ & 72.89 \\
\hline $3^{\prime}$ & $3.61(\mathrm{~m})$ & 75.99 & $3.76(\mathrm{~m})$ & 82.58 \\
\hline $4^{\prime}$ & $4.94(t, 9.5)$ & 72.51 & $4.73(t, 9.5)$ & 69.17 \\
\hline $5^{\prime}$ & $3.67(t, 9.5)$ & 74.92 & $3.26(t, 9.5)$ & 73.20 \\
\hline $6^{\prime}$ & $3.50^{c}, 3.74^{c}$ & 67.87 & $3.35^{c}, 3.58^{c}$ & 66.10 \\
\hline \multicolumn{5}{|l|}{ Rhamnose } \\
\hline $1 "(1 " ')$ & $4.65(\mathrm{~d}, 1.5)$ & 102.44 & $4.52(\mathrm{~d}, 1.5)$ & 100.62 \\
\hline $2 "\left(2^{\prime \prime \prime}\right)$ & $3.84(\mathrm{~m})$ & 72.15 & $3.84(\mathrm{~m})$ & 69.93 \\
\hline 3" (3"') & $3.65(\mathrm{~m})$ & 72.43 & $3.65(\mathrm{~m})$ & 70.57 \\
\hline 4" (4'") & $3.35(t, 9.5)$ & 74.08 & $2.92(t, 9.5)$ & 71.83 \\
\hline 5" (5'") & $3.65(\mathrm{~m})$ & 70.02 & $3.65(\mathrm{~m})$ & 68.44 \\
\hline 6" (6'") & $1.20(\mathrm{~d}, 6.5)$ & 18.16 & $1.05(\mathrm{~d}, 6.5)$ & 17.81 \\
\hline \multicolumn{5}{|c|}{ Outer glucose } \\
\hline 1"' (1") & & & $4.38(\mathrm{~d}, 7.5)$ & 104.57 \\
\hline 2"' (2") & & & $3.12^{c}$ & 74.37 \\
\hline 3"' (3") & & & $3.35^{c}$ & 76.29 \\
\hline 4'" (4") & & & $3.59^{c}$ & 70.28 \\
\hline $5 " '(5 ")$ & & & $3.03^{c}$ & 76.94 \\
\hline 6"' (6") & & & $3.25^{a}, 3.51^{c}$ & 61.01 \\
\hline \multicolumn{5}{|l|}{ Ester moiety } \\
\hline 1 "' (1"') & & 127.81 & & 125.77 \\
\hline $2^{\prime \prime \prime}\left(2^{\prime \prime \prime \prime}\right)$ & $7.20(\mathrm{~d}, 2.0)$ & 111.95 & $7.31(\mathrm{~d}, 2.0)$ & 110.98 \\
\hline $3^{\prime \prime \prime}\left(3^{\prime \prime \prime \prime}\right)$ & & 149.53 & & 147.91 \\
\hline 4"' (4"'") & & 150.90 & & 149.26 \\
\hline $5^{\prime \prime \prime}\left(5^{\prime \prime \prime}\right)$ & $6.82(\mathrm{~d}, 8.0)$ & 116.65 & $6.82(\mathrm{~d}, 8.0)$ & 115.50 \\
\hline 6"' (6"'") & $7.09(\mathrm{dd}, 8.0,2.0)$ & 124.37 & $7.10(\mathrm{dd}, 8.0,2.0)$ & 123.09 \\
\hline 7"' (7"'") & $7.66(\mathrm{~d}, 16.0)$ & 147.66 & $7.53(\mathrm{~d}, 16.0)$ & 144.96 \\
\hline $8^{\prime \prime \prime}\left(8^{\prime \prime \prime \prime)}\right.$ & $6.40(\mathrm{~d}, 16.0)$ & 115.28 & $6.48(\mathrm{~d}, 16.0)$ & 114.65 \\
\hline $9^{\prime \prime \prime}\left(9^{\prime \prime \prime)}\right.$ & & 168.40 & & 165.84 \\
\hline $\mathrm{OCH}_{3}$ & $3.90(\mathrm{~s})$ & 56.61 & $3.81(\mathrm{~s})$ & 56.60 \\
\hline
\end{tabular}

${ }^{a}$ In $\mathrm{CD}_{3} \mathrm{OD} .{ }^{b}$ In DMSO- $d_{6} .{ }^{c}$ Overlapped with other signals.

661.2108). The ${ }^{1} \mathrm{H}$ - and ${ }^{13} \mathrm{C}-\mathrm{NMR}$ spectral data of 1 were quite similar to those of forsythiaside (4) $)^{7}$ except for the presence of a feruloyl group instead of a caffeoyl group in 4 . In the ${ }^{1} \mathrm{H}-\mathrm{NMR}$ spectrum, feruloyl and 3,4-dihydroxy phenylethyl groups confirmed by the six aromatic proton signals between $\delta_{\mathrm{H}} 6.57-7.20$ for $2 \mathrm{ABX}$ systems, two olefinic protons at $\delta_{\mathrm{H}} 6.40$ and $\delta_{\mathrm{H}} 7.66$, a benzylic methylene proton at $\delta_{\mathrm{H}} 2.81(2 \mathrm{H}, \mathrm{m})$, and two nonequivalent protons at $\delta_{\mathrm{H}} 3.73(1 \mathrm{H}, \mathrm{dd}, J=16.0,8.0 \mathrm{~Hz})$ and $\delta_{\mathrm{H}}$ $3.99(1 \mathrm{H}, \mathrm{dd}, J=16.0,8.0 \mathrm{~Hz})$. The location of the methoxy group was determined by the NMR spectral data comparison of 1 and 4 , and by NOESY correlation between $\delta_{\mathrm{H}} 3.90\left(-\mathrm{OCH}_{3}\right)$ and $\delta_{\mathrm{H}} 7.20(\mathrm{H}-2 " ', \mathrm{~d}, J=2.0 \mathrm{~Hz})$. Moreover, in the ${ }^{13} \mathrm{C}-\mathrm{NMR}$ spectrum, in addition to signals attributable to the 3,4-dihy- droxyphenylethyl and feruloyl groups, revealed signals for 12 carbons corresponding to the carbohydrate moiety. In the ${ }^{1} \mathrm{H}-$ and ${ }^{13} \mathrm{C}$-NMR spectra, the anomeric protons at $\delta_{\mathrm{H}} 4.37(1 \mathrm{H}, \mathrm{d}$, $J=8.0 \mathrm{~Hz}), \delta_{\mathrm{H}} 4.65(1 \mathrm{H}, \mathrm{d}, J=1.5 \mathrm{~Hz})$ indicated that 1 contained one glucopyranosyl and one rhamnopyranosyl unit. ${ }^{8-9}$ And these findings matched those in the HSQC spectrum, where two corresponding carbon signals appeared at $\delta_{\mathrm{C}} 104.65$ and 102.44 respectively. The presence of these sugar moieties were further confirmed by the acid hydrolysis of 1 which resulted in a release of D-glucose and L-rhamnose, identified by TLC comparison with the authentic samples. ${ }^{10}$ The configuration of the glucopyranosyl and rhamnopyranosyl were assigned to be $\beta$ and $\alpha$-, respectively, according to the coupling constant of the 
Table 2. Antioxidative Activities of Compounds 1, 3 and $\mathbf{4}$ from Digitalis purpurea $\mathrm{L}$.

\begin{tabular}{cc}
\hline Compounds & $\mathrm{IC}_{50}(\mu \mathrm{g} / \mathrm{mL})$ \\
\hline Purpureaside D (1) & $38.10 \pm 2.42^{* *}$ \\
Purpureaside E (3) & $18.35 \pm 3.74 * *$ \\
Forsythiaside (4) $^{\star}$ & $7.98 \pm 2.02^{* *}$ \\
Allopurinol $^{\star}$ & $3.38 \pm 1.60$
\end{tabular}

${ }^{\star}$ Used as a positive control. Each value is the mean \pm S.D. of three experiments. ${ }^{* *} p<0.001$ compared with control value.

anomeric proton. ${ }^{11}$ The detailed ${ }^{1} \mathrm{H}-,{ }^{13} \mathrm{C}-,{ }^{1} \mathrm{H}-{ }^{1} \mathrm{H}-\mathrm{COSY}$, HSQC, and $\mathrm{HMBC}$ spectra of $\mathbf{1}$ fixed the connections between the moieties. The significant deshielding of $\mathrm{H}-4^{\prime}\left(\delta_{\mathrm{H}} 4.94\right)$ and the HMBC correlation between H-4' and C-9'"' $\left(\delta_{\mathrm{C}} 168.40\right)$ confirmed that the feruloyl group was attached to C-4'. In addition, a downfield shift of C- 6 ' $\left(\delta_{\mathrm{C}} 67.87\right)$ and the HMBC correlation between $\mathrm{H}-6^{\prime}\left(\delta_{\mathrm{H}} 3.50\right.$ and $\left.\delta_{\mathrm{H}} 3.74\right)$ and $\mathrm{C}-1 "{ }^{\prime \prime}\left(\delta_{\mathrm{C}} 102.44\right)$ suggested that rhamnose was attached to $\mathrm{C}-6 \cdot{ }^{12}$ Based on the above results, the structure of $\mathbf{1}$ is proposed to be 2-(3,4-dihydroxyphenyl)ethyl- $O-\alpha$-L-rhamnopyranosyl-(1-6)-4- $O$ [(E)-feruloyl]- $\beta$-D-glucopyranoside, named, purpureaside D.

Compound $\mathbf{3}$ was obtained as a white amorphous powder, with $[\alpha]_{D}^{25}-16.2^{\circ}$. Its molecular formula was determined to be $\mathrm{C}_{36} \mathrm{H}_{48} \mathrm{O}_{20}$ by negative HR-FAB-MS ([M-H] ${ }^{-}$at $m / z$ 799.2673, calc. 799.2739). Furthermore, the FAB-MS/MS spectrum showed the molecular ion and main fragments at $m / z 799[\mathrm{M}-\mathrm{H}]^{-}$, $653[\mathrm{M}-\mathrm{rha}]^{+}, 623\left[\mathrm{M}-\mathrm{rha}-\mathrm{OCH}_{2}\right]^{+}, 637$ [M-rha-O $]^{+}$. The ${ }^{1} \mathrm{H}-$, ${ }^{13} \mathrm{C}$-NMR spectra of $\mathbf{3}$ (Table 1) showed that the signals were in good agreement with those from $\mathbf{1}$, except for the existence of an additional hexose moiety. In the ${ }^{1} \mathrm{H}-{ }^{13} \mathrm{C}$-NMR spectra of 3 , anomeric protons at $\delta_{\mathrm{H}} 4.42(1 \mathrm{H}, \mathrm{d}, J=8.0 \mathrm{~Hz}) \delta_{\mathrm{C}} 102.23$; $\delta_{\mathrm{H}} 4.38(1 \mathrm{H}, \mathrm{d}, J=7.5 \mathrm{~Hz}) \delta_{\mathrm{C}} 104.57$, and $\delta_{\mathrm{H}} 4.52(1 \mathrm{H}, \mathrm{d}, J=$ $1.5 \mathrm{~Hz}) \delta_{\mathrm{C}} 100.62$ were observed. These data suggested that 3 contained two $\beta$-D-glucoses and one $\alpha$-L-rhamnose as sugar units. ${ }^{13-15}$ Furthermore, the presence of these sugar moieties was confirmed by the acid hydrolysis of $\mathbf{3}$, as carried out with 1. ${ }^{10}$ In addition, the configuration of the glucopyranosyl and rhamnopyranosyl of $\mathbf{3}$ appeared to be the same as those of $\mathbf{1}$, based on the coupling constant of the anomeric proton. ${ }^{11}$ Moreover, the deshielding of $\mathrm{H}-4^{\prime}\left(\delta_{\mathrm{H}} 4.73\right)$ and the HMBC correlation between H-4' and C-9"' $\left(\delta_{\mathrm{C}} 165.84\right)$ confirmed that the feruloyl group was attached to C-4'. In addition, a downfield shift of C- $6^{\prime}\left(\delta_{\mathrm{C}} 67.87\right)$ and the HMBC correlation between H-6' $\left(\delta_{\mathrm{H}} 3.35\right.$ and $\left.\delta_{\mathrm{H}} 3.58\right)$ and $\mathrm{C}-1 " '\left(\delta_{\mathrm{C}} 100.62\right)$ suggested that rhamnose was attached to C-6'. Also, a downfield shift of H-3' $\left(\delta_{\mathrm{H}} 3.76\right)$ and the HMBC correlation between $\mathrm{H}-3^{\prime}$ and $\mathrm{C}-1$ " $\left(\delta_{\mathrm{C}}\right.$ 104.57) revealed that terminal glucose was attached to C-3'. Based on the above results, the structure of $\mathbf{3}$ is proposed to be 2-(3,4-dihydroxyphenyl)ethyl- $O$ - $\alpha$-L-rhamnopyranosyl(1-6)-O- $\beta$-D-glucopyranosyl-(1-3)-4-O-[(E)-feruloyl]- $\beta$-Dglucopyranoside, named, purpureaside $\mathrm{E}$.

In addition, compound $\mathbf{2}$, which was not reported previously from this plant, was identified as scroside $\mathrm{D},{ }^{8}$ and compound 4 was identified as forsythiaside, ${ }^{7}$ respectively, by comparing the ${ }^{1} \mathrm{H}-,{ }^{13} \mathrm{C}$-, and 2D-NMR spectroscopic data with those of reported in the literature.
The antioxidative activities of the isolated compounds were tested by a NBT superoxide scavenging assay. As shown in Table 2, compounds $\mathbf{1}$ and $\mathbf{3}$ showed similar antioxidative activities. When comparing the antioxidative activities of compounds $\mathbf{1}$ and $\mathbf{3}$ to that of compound $\mathbf{4}$, compound $\mathbf{4}$ was more potent than compounds $\mathbf{1}$ and $\mathbf{3}$. In order to understand what makes compounds $\mathbf{1}$ and $\mathbf{3}$ different from compound $\mathbf{4}$ in the antioxidative activity, their chemical structures were compared. As shown in Chart 1, the distinct structural difference is that compounds $\mathbf{1}$ and $\mathbf{3}$ have a C-4' feruloyl substituent in sugar part, while compound $\mathbf{4}$ has a C-4' caffeoyl group in sugar part. These results suggest that the ortho-dihydroxy (catechol) structure play an important role in the antioxidative function as exhibited in flavonoids. ${ }^{16-18}$

\section{Experimental}

General Procedures. Optical rotations were measured using an Autopol-IV polarimeter. UV spectra were obtained on a Shimadzu UV/Visible Spectrophotometer. The IR spectra were measured in $\mathrm{KBr}$ pellets using an IMS 85 (Bruker). The NMR spectra were recorded on a Varian Unity Inova 500 spectrometer. HR-FAB-MS was recorded on a JEOL JMS 700 mass spectrometer (KBSI-Gwangju center). TLC and the preparative TLC were carried out on precoated Silica gel 60 $\mathrm{F}_{254}$ (Merck, art. 5715) and RP-18 $\mathrm{F}_{254} \mathrm{~S}$ (Merck, art. 15389) plates. Column chromatography was performed on Silica gel 60 (Merck, $40-63$ and $63-200 \mu \mathrm{m}$ ), MCI gel CHP 20P (Mitsubishi Chemical Co., 70-150 $\mu \mathrm{m}$ ), and Sephadex LH-20 (Sigma, $25-100 \mu \mathrm{m}$ ).

Plant Material. The leaves of Digitalis purpurea L. (Scrophulariaceae) was collected in the Herbarium of College of Pharmacy, Chosun University, Korea, in July 2006 and authenticated by Professor Emeritus Young Hee Moon of College of Pharmacy, Chosun University, Korea. Voucher specimens were deposited in the Herbarium of the College of Pharmacy, Chosun University, Korea (997-17).

Extraction and Isolation. The dried leaves ( $180 \mathrm{~g})$ of $D$. purpurea were extracted with $\mathrm{MeOH}$ three times at room temperature and $80.6 \mathrm{~g}$ of residue were produced. The $\mathrm{MeOH}$ extract was suspended in $\mathrm{H}_{2} \mathrm{O}$ and partitioned sequentially in $\mathrm{CH}_{2} \mathrm{Cl}_{2}$, EtOAc, and $n$-BuOH. The EtOAc fraction $(5.5 \mathrm{~g})$ was chromatographed over a silica gel column using a gradient solvent system of $\mathrm{CHCl}_{3}-\mathrm{MeOH}-\mathrm{H}_{2} \mathrm{O}(8: 1: 0.1 \rightarrow 6: 1: 0.1 \rightarrow 4: 1: 0.1 \rightarrow 2: 1:$ $0.1 \rightarrow 1: 1: 0.1, \mathrm{MeOH}$ only) to give subfractions, designated as E1-E10. Subfraction E7 (543 mg) was further purified by column chromatography over a Sephadex LH20 eluting with a MeOH to afford seven subfractions (E71-E75). Subfraction E73 (63.9 $\mathrm{mg}$ ) was purified by RP-18 CC eluting with an $i \mathrm{PrOH}: \mathrm{MeOH}$ : $\mathrm{H}_{2} \mathrm{O}$ (5:35:65) and Sephadex LH 20 CC eluting with MeOH: $\mathrm{H}_{2} \mathrm{O}(9: 1)$ to give compound $\mathbf{1}$ (13.08 $\mathrm{mg}$, purpureaside $\mathrm{D}$ ), and 2 (scroside D, 3.35mg). Subfraction E9 (2074.77 mg) was purified by CC over a Sephadex LH 20 to afford seven subfractions (E91-97). Subfraction E92 (30.5 mg) was purified by RP-18 CC eluting with an $i \mathrm{PrOH}: \mathrm{MeOH}: \mathrm{H}_{2} \mathrm{O}(5: 30: 70)$ to give compound 3 (purpureaside E, $15.05 \mathrm{mg}$ ). Subfraction E94 (514.4 mg) was finally purified by repeated RP-18 CC eluting with an $i-\mathrm{PrOH}$ : $\mathrm{MeOH}: \mathrm{H}_{2} \mathrm{O}(5: 25: 75)$, which afforded compound 4 (forsythia- 
side, $25.3 \mathrm{mg})$.

Compound 1 (purpureaside D): Yellow powder, $[\alpha]_{\mathrm{D}}^{25}-191.3^{\circ}$ (c $0.5, \mathrm{MeOH})$; UV $\lambda_{\max }(\mathrm{MeOH}) \mathrm{nm}(\log \varepsilon) 219$ (4.20), 288 (3.55), 328 (4.00); IR (KBr) cm ${ }^{-1}: 3400,1705,1635,1593,1515$, 1430, 1155; ${ }^{1} \mathrm{H}$ - and ${ }^{13} \mathrm{C}-\mathrm{NMR}$, see Table 1 ; HR-FAB-MS $\mathrm{m} / \mathrm{z}$ $661.2106[\mathrm{M}+\mathrm{Na}]^{+}$(calcd for $\mathrm{C}_{30} \mathrm{H}_{38} \mathrm{O}_{15} \mathrm{Na}: 661.2108$ ).

Compound 2 (scroside D): Yellow amorphous powder, $[\alpha]_{\mathrm{D}}^{25}$ $-44.0^{\circ}$ (c 0.4, MeOH); ${ }^{1} \mathrm{H}-\mathrm{NMR}\left(\mathrm{CD}_{3} \mathrm{OD}, 500 \mathrm{MHz}\right) \delta 6.70(1 \mathrm{H}$, $\mathrm{d}, J=2.0 \mathrm{~Hz}, \mathrm{H}-2), 6.68(1 \mathrm{H}, \mathrm{d}, J=8.5 \mathrm{~Hz}, \mathrm{H}-5), 6.57(1 \mathrm{H}, \mathrm{dd}$, $J=8.5,2.0 \mathrm{~Hz}, \mathrm{H}-6), 2.80$ (2H, m, H-7), 4.05 (1H, dd, $J=16.0$, $8.0 \mathrm{~Hz}, \mathrm{H}-8), 3.74$ (1H, m, H-8), 4.42 (1H, d, $\left.J=8.0 \mathrm{~Hz}, \mathrm{H}-1^{\prime}\right)$, $3.56\left(1 \mathrm{H}, \mathrm{m}, \mathrm{H}-2^{\prime}\right), 3.95\left(1 \mathrm{H}, \mathrm{t}, J=9.5 \mathrm{~Hz}, \mathrm{H}-3^{\prime}\right), 4.94(1 \mathrm{H}, \mathrm{t}$, $\left.J=9.5 \mathrm{~Hz}, \mathrm{H}-4^{\prime}\right), 3.50$ (1H, t, $\left.J=9.5 \mathrm{~Hz}, \mathrm{H}-5^{\prime}\right), 3.55(1 \mathrm{H}, \mathrm{m}$, H-6'), 3.70 (1H, m, H-6'), 4.55 (1H, d, J=7.5 Hz, H-1"), 3.15 (1H, m, H-2"), 3.35 (1H, t, $\left.J=9.5 \mathrm{~Hz}, \mathrm{H}-3^{\prime \prime}\right), 3.22$ (1H, m, H-4"), 3.19 (1H, m, H-5"), 3.51 (1H, m, H-6"), 3.64 (1H, m, H-6"), 7.29 (1H, d, $\left.J=2.0 \mathrm{~Hz}, \mathrm{H}-2^{\prime \prime \prime}\right), 6.82(1 \mathrm{H}, \mathrm{d}, J=8.5 \mathrm{~Hz}$, H-5"'), 7.10 (1H, dd, $J=8.5,2.0 \mathrm{~Hz}, \mathrm{H}-6 " '), 7.65$ (1H, d, $J=$ $16.0 \mathrm{~Hz}, \mathrm{H}-7$ "') $^{2} 6.43$ (1H, d, $\left.J=16.0 \mathrm{~Hz}, \mathrm{H}-8^{\prime \prime \prime}\right), 3.90$ (3H, s, $\left.-\mathrm{OCH}_{3}\right) ;{ }^{13} \mathrm{C}-\mathrm{NMR}\left(\mathrm{CD}_{3} \mathrm{OD}, 125 \mathrm{MHz}\right) \delta 131.57(\mathrm{C}-1), 117.28$ (C-2), 146.28 (C-3), 144.83 (C-4), 116.45 (C-5), 121.41 (C-6), 36.70 (C-7), 72.38 (C-8), 104.16 (C-1'), 76.06 (C-2'), 84.33 (C-3'), 71.02 (C-4'), 75.25 (C-5'), 67.45 (C-6'), 105.87 (C-1"), 76.12 (C-2"), 77.86 (C-3"), 71.47 (C-4"), 78.16 (C-5"), 62.65 (C-6"), 127.86 (C-1"'), 111.90 (C-2"'), 149.58 (C-3"'), 150.90 (C-4"'), 116.66 (C-5"'), 124.43 (C-6"'), 147.43 (C-7"'), 115.74 (C-8"'), 168.68 (C-9"'), $56.63\left(-\mathrm{OCH}_{3}\right)$.

Compound 3 (purpureaside E): White amorphous powder, $[\alpha]_{\mathrm{D}}^{25}-16.1^{\circ}$ (c 0.9, MeOH); UV $\lambda_{\max }(\mathrm{MeOH}) \mathrm{nm}(\log \varepsilon) 218$ (4.25), 289 (3.60), 328 (4.05); IR (KBr) cm $\mathrm{cm}^{-1}$ :3405, 1702, 1633, 1590, 1513, 1435, 1150; ${ }^{1} \mathrm{H}$ - and ${ }^{13} \mathrm{C}$-NMR, see Table 1; HRFAB-MS (negative) $m / z 799.2673[\mathrm{M}-\mathrm{H}]^{-}$(calcd for $\mathrm{C}_{36} \mathrm{H}_{47} \mathrm{O}_{20}$ : 799.2739).

Compound 4 (forsythiaside): Yellow amorphous powder, $[\alpha]_{\mathrm{D}}^{25}-17.8^{\circ}$ (c 1.0, MeOH); ${ }^{1} \mathrm{H}-\mathrm{NMR}\left(\mathrm{CD}_{3} \mathrm{OD}, 500 \mathrm{MHz}\right) \delta 6.70$ $(1 \mathrm{H}, \mathrm{d}, J=2.0 \mathrm{~Hz}, \mathrm{H}-2), 6.69(1 \mathrm{H}, \mathrm{d}, J=8.0 \mathrm{~Hz}, \mathrm{H}-5), 6.57$ (1H, dd, $J=8.0,2.0 \mathrm{~Hz}, \mathrm{H}-6), 2.80$ (2H, m, H-7), 3.73 (1H, dd, $J=16.0,8.0 \mathrm{~Hz}, \mathrm{H}-8), 3.99$ (1H, dd, $J=16.0,8.0 \mathrm{~Hz}, \mathrm{H}-8)$, $4.37\left(1 \mathrm{H}, \mathrm{d}, J=8.0 \mathrm{~Hz}, \mathrm{H}-1^{\prime}\right), 3.31\left(1 \mathrm{H}, \mathrm{m}, \mathrm{H}-2^{\prime}\right), 3.61(1 \mathrm{H}, \mathrm{m}$, H-3'), 4.92 (1H, t, $\left.J=9.5 \mathrm{~Hz}, \mathrm{H}-4^{\prime}\right) 3.67(1 \mathrm{H}, \mathrm{t}, J=9.5 \mathrm{~Hz}$, H-5'), 3.50 (1H, m, H-6'), 3.74 (1H, m, H-6'), 4.64 (1H, d, $J=$ 1.5 Hz, H-1"), 3.84 (1H, m, H-2"), 3.65 (2H, m, H-3", 5"), 3.35 $(1 \mathrm{H}, \mathrm{t}, J=9.5 \mathrm{~Hz}, \mathrm{H}-4 "), 1.20$ (3H, d, $J=6.5 \mathrm{~Hz}, \mathrm{H}-6 "), 7.06$ $\left(1 \mathrm{H}, \mathrm{d}, J=2.0 \mathrm{~Hz}, \mathrm{H}-2^{\prime \prime \prime}\right), 6.78\left(1 \mathrm{H}, \mathrm{d}, J=8.0 \mathrm{~Hz}, \mathrm{H}-5{ }^{\prime \prime}\right), 6.96$ (1H, dd, $\left.J=8.0,2.0 \mathrm{~Hz}, \mathrm{H}-66^{\prime \prime}\right), 7.60$ (1H, d, $\left.J=16.0 \mathrm{~Hz}, \mathrm{H}-7{ }^{\prime \prime}\right)$, $6.30\left(1 \mathrm{H}, \mathrm{d}, J=16.0 \mathrm{~Hz}, \mathrm{H}-8^{\prime \prime \prime}\right) ;{ }^{13} \mathrm{C}-\mathrm{NMR}\left(\mathrm{CD}_{3} \mathrm{OD}, 125 \mathrm{MHz}\right)$ $\delta 131.55(\mathrm{C}-1), 117.26(\mathrm{C}-2), 146.25$ (C-3), 144.82 (C-4), 116.51 (C-5), 121.43 (C-6), 36.80 (C-7), 72.51 (C-8), 104.63 (C-1'), 75.31 (C-2'), 75.97 (C-3'), 72.51 (C-4'), 74.91 (C-5'), 67.82 (C-6'), 102.42 (C-1"), 72.15 (C-2"), 72.42 (C-3"), 74.09 (C-4"), 70.01 (C-5"), 18.15 (C-6"), 127.81 (C-1"'), 114.89 (C-2"'), 146.97 (C-3"'), 149.87 (C-4"'), 116.67 (C-5"'), 123.25 (C-6"'), 147.77 (C-7"'), 115.37 (C-8"'), 168.43 (C-9"').

Acidic Hydrolyses of Compounds 1, and 3. Compounds 1 and 3 ( $3 \mathrm{mg}$ each) were dissolved in $1 \mathrm{~N} \mathrm{HCl}(0.6 \mathrm{~mL})$ and $\mathrm{MeOH}(0.6 \mathrm{~mL})$, and refluxed at $75^{\circ} \mathrm{C}$ for $90 \mathrm{~min}$. The reaction solution was evaporated under reduced pressure, and the hydrolysate was extracted with EtOAc $(2 \mathrm{~mL} \times 3)$. The aqueous fraction was neutralized with $\mathrm{Ag}_{2} \mathrm{CO}_{3}$ and filtered. The filtrate was then concentrated under reduced pressure. ${ }^{10}$ The residue was compared with a standard sugar using TLC, which revealed the sugar to be D- $(+)$-glucose $\left(R_{f}=0.26\right)$, and L- $(+)$-rhamnose $\left(R_{f}=0.46\right)$ in 1 and 3.

NBT Superoxide Scavenging Assay. The NBT superoxidescavenging assay was carried out using a slight modification of an established method. ${ }^{19-20}$ The reaction mixture, which was equilibrated at $25^{\circ} \mathrm{C}$, contained $20 \mu \mathrm{L}$ of a $15 \mathrm{mM} \mathrm{Na} \mathrm{EDTA}$ solution in a buffer $\left(50 \mathrm{mM} \mathrm{KH} \mathrm{PO}_{4} / \mathrm{KOH} \mathrm{pH} 7.4\right.$ in ionized water), $50 \mu \mathrm{L}$ of $0.6 \mathrm{mM} \mathrm{NBT}$ in a buffer, $30 \mu \mathrm{L}$ of a $3 \mathrm{mM}$ hypoxanthine in $50 \mathrm{mM} \mathrm{KOH}$ solution, $50 \mu \mathrm{L}$ of xanthine oxidase solution in a buffer ( 1 unit in $10 \mathrm{~mL}$ buffer) and $100 \mu \mathrm{L}$ of the sample. The plate reader (Molecular Devices Vmax) took readings every $20 s$ for $5 \mathrm{~min}$ at $570 \mathrm{~nm}$. The control was 100 $\mu \mathrm{L}$ of $5 \%$ DMSO solution instead of the sample. Results were expressed as relative percentage inhibition to control, given by [(rate of control - rate of sample reaction $) /$ rate of control] $\times$ 100. Allopurinol was used as a reference compound.

Acknowledgments. This work was supported by research funds from Chosun University in 2011.

\section{References}

1. Navarro, E.; Alonso, P. J.; Alonso, S. J.; Trujillo, J.; Pérez, C.; Toro, M. V.; Ayuso, M. J. J. Ethnopharmacol. 2000, 71, 437.

2. Hauptman, P. J.; Kelly, R. A. Circulation 1999, 99, 1265.

3. López-Lázaro, M.; Palma De La Peña, N.; Pastor, N.; Martín-Cordero, C.; Navarro, E.; Cortés F.; Ayuso, M. J.; Toro, M. V. Planta Med. 2003, 69, 701

4. Lee, J. Y.; Woo, E.-R.; Kang, K. W. Pharmazie 2006, 61, 356.

5. Choi, D. Y.; Lee, J. Y.; Kim, M. R.; Woo, E.-R.; Kim, Y. G.; Kang, K. W. J. Biomed. Sci. 2005, 12, 949.

6. Oh, J. W.; Lee, J. Y.; Han, S. H.; Moon, Y. H.; Kim, Y. G.; Woo, E.-R.; Kang, K. W. J. Pharm. Pharmacol. 2005, 57, 903.

7. Matsumoto, M.; Koga, A.; Shoyama, Y.; Nishioka, I. Phytochemistry 1987, 26, 3225 .

8. Zhu, T. F.; Huang, K. Y.; Deng, X. M.; Zhang, Y.; Xiang, H.; Gao, H. Y.; Wang, D. C. Molecules 2008, 13, 729.

9. Huang, S.-X.; Liao, X.; Nie, Q.-J.; Ding, L.-S.; Peng, S.-L. Helv. Chim. Acta 2004, 87, 598 .

10. Kim, M. R.; Moon, H. I.; Chung, J. H.; Moon, Y. H.; Hahm, K. S.; Woo, E.-R. Chem. Pharm. Bull. 2004, 52, 1466.

11. Sang, S. M.; Lao, A.; Wang, H. C.; Chen, Z. Phytochemistry 1999, $52,1611$.

12. Saracoglu, I.; Harput, U. S.; Inoue, M.; Ogihara, Y. Chem. Pharm. Bull. 2002, 50, 665 .

13. Zhou, B.-N.; Bahler, B. D.; Hofmann, G. A.; Mattern, M. R.; Johnson, R. K.; Kingston, D. G. J. Nat. Prod. 1998, 61, 1410.

14. Miyase, T.; Ishino, M.; Akahori, C.; Ueno, A.; Ohkawa, Y.; Tanizawa, H. Phytochemistry 1991, 30, 2015.

15. Gao, J.; Igarashi, K.; Nukina, M. Chem. Pharm. Bull. 2000, 48, 1075

16. Pietta, P-G. J. Nat. Prod. 2000, 63, 1035.

17. Akdemir, Z. Ş.; Tati, İI.; Saraccoğlu, İ.; İsmailoğlu, U. B.; ŞahinErdemli, İ.; Calis, İ. Phytochemistry 2001, 56, 189.

18. Woo, E.-R.; Piao, M. S. Arch. Pharm. Res. 2004, 27, 173.

19. Kirby, A. J.; Schmidt, R. J. J. Ethnopharmacol. 1997, 56, 103.

20. Han, S.-H.; Lee, H.-H.; Lee, I.-S.; Moon, Y. H.; Woo, E.-R. Arch. Pharm. Res. 2002, 25, 433. 